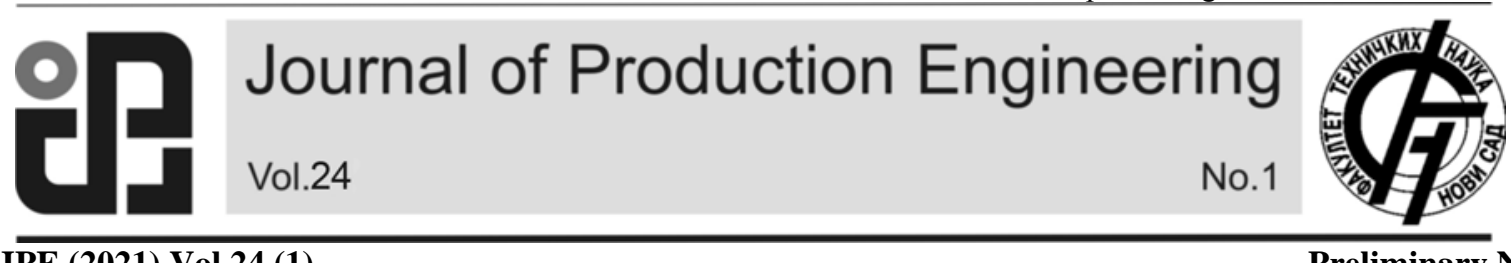

JPE (2021) Vol.24 (1)

Tamás, P.,Varga A. K.

\title{
THE ROLE OF PROPOSAL MANAGEMENT SYSTEMS IN THE PRODUCTION AND SERVICE
}

Received: 13 April 2021 / Accepted: 18 June 2021

Abstract: One of the most effective ways to increase the efficiency of logistics processes is to use different tools and methods of lean. Lean initially developed in the field of production, but today it has also become dominant in the service sector. The paper presents one of the basic tools of lean, i.e. the proposal management system, with the help of which the 8th type of loss, namely the non-utilization of the knowledge and creativity of the employees can be reduced. Theoretical background of the application of the tool, its application possibilities, and its application through a practical example are described.

Keywords: Proposal management system, loss reduction, lean philosophy, web based system development.

Uloga sistema upravljanja predlozima u proizvodnji i usluzi. Jedan od najefikasnijih načina za povećanje efikasnosti logističkih procesa je upotreba različitih alata i Lean metodai. Lean se u početku razvijao na polju proizvodnje, ali danas je postao dominantan $i$ u uslužnom sektoru. U radu je predstavljen jedan od osnovnih Lean alata, odnosno sistem upravljanja predlozima, uz pomoć kojeg se može smanjiti osam tipova gubitaka, odnosno neiskorišćenost znanja i kreativnosti zaposlenih. Opisana je teorijska osnova primene alata, njegove mogućnosti primene i primena kroz praktični primer.

Ključne reči: Sistem upravljanja predlozima, smanjenje gubitaka, Lean filozofija, razvoj sistema zasnovan na mreži.

\section{INTRODUCTION}

Today, most manufacturing and service companies are increasingly focusing on eliminating the losses inherent in their processes, thanks to the fact that efficient process development has become a key determinant of competitiveness. The tool and set of rules defined by the lean philosophy make it possible to reduce the losses shown in Figure 1.

In the words of Taichi Ohno, the essence of lean philosophy is to reduce the time between order and receipt of money by eliminating losses [1]. Of these losses, only the non-utilization of the knowledge and creativity of the employees is examined in the paper. In most companies, the established organizational culture treats the development of processes and the performance of operational tasks separately, so there is no possibility for the development proposals of employees at the operational level to be formulated and implemented.

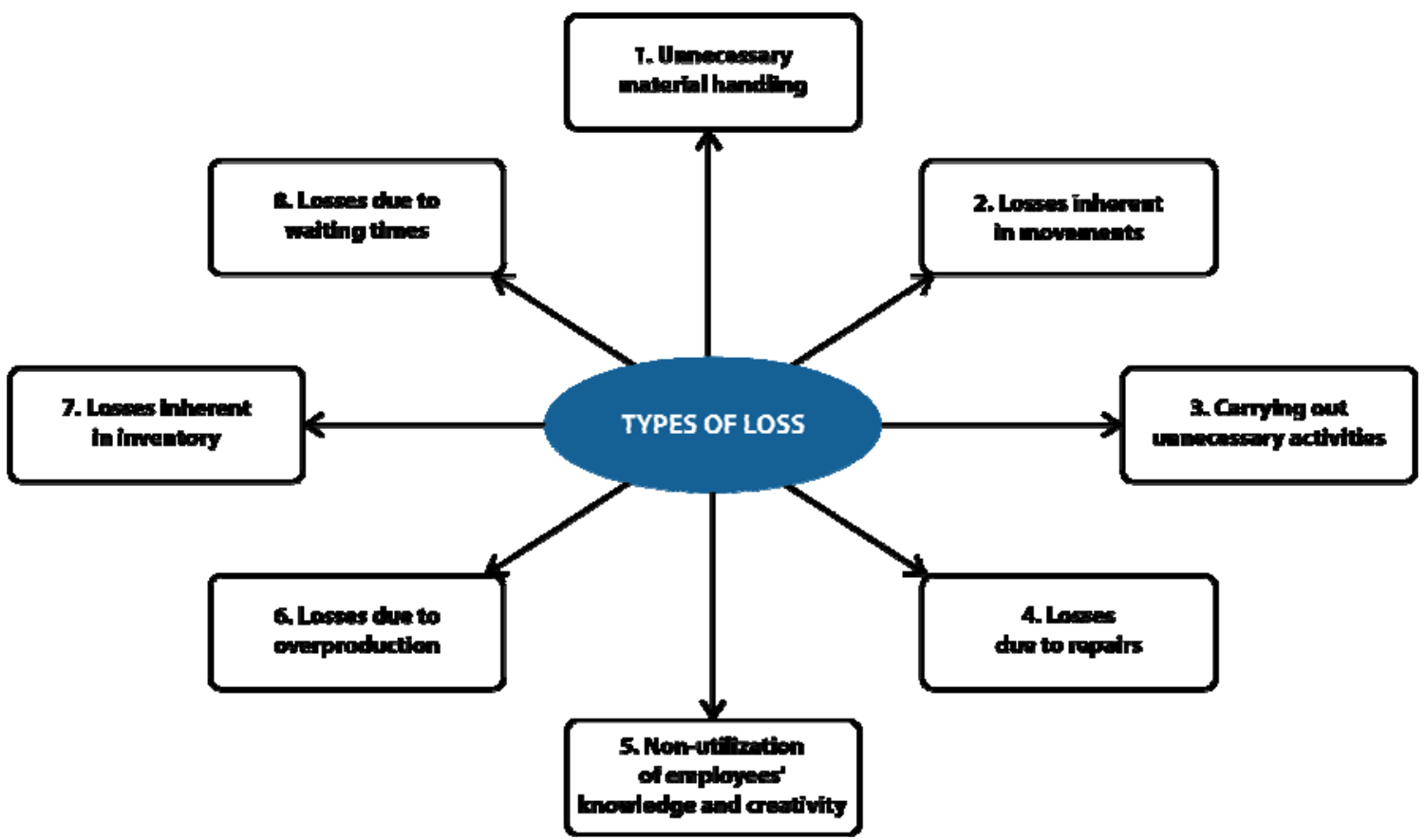

Fig. 1. Types of losses [own constructions] 
This does not seem to be a significant problem at first, but if we consider that e.g. with Volkswagen earning $€ 49$ million in 2015 through the operation of its bidding system [2], many market players are already considering the introduction of this method. In the further part of the paper the application areas of proposal management systems and the process of their implementation, as well as the process of the implementation of the proposal management system (hereinafter, the proposal system and the proposal management system have the same meaning) developed by the Institute of Logistics of the University of Miskolc for the development of the institutional processes are presented.

\section{FIELDS OF APPLICATION OF PROPOSAL SYSTEMS, PROCESS OF DEVELOPMENT}

Proposal systems were initially set up in the production areas of vehicle manufacturers, and then more and more sectors recognized the potential of applying the method. Without wishing to be exhaustive, the most important areas of application of the method are the logistics service sector, the food industry and hospitality. It can be said that the method can be applied with great success in those areas where the degree of automation of the tasks is low, so their performance is typically performed by human resources. This is due to the fact that with the increase in the number of employees and the decrease in the level of organization of the processes, the potential for the utilization of the knowledge and creativity of the employees increases. The application of the method can result in several advantages for the companies implementing the implementation, these are:

- greater use of the knowledge and creativity of the employees of the examined organization,

- $\quad$ improving employee engagement with the organization,

- development of organizational culture,

- more intensive process development,

- improving the professional competences of employees,

- increase in employee satisfaction.

During the application of the method, the steps of two sub-processes, ie the planning and the proposal process, have to be implemented. The steps in the design process are as follows [3]:

1. Development of a motivation system.

2. Establishment of an organization responsible for the operation.

3. Development of operational processes and a unified set of rules.

4. Development of applicable forms.

5. Develop a concept for applicable software support.

6. Defining the ranking indicators of the proposal management system.

During the planning process, after the development of the motivation system necessary for the operation of the proposal system, an accurate description of the operation of the system must be realized.

The implementation of the planned system should be carried out in a 7-step process. These steps are as follows [3]:

1. Determining the implementation schedule and cost allocation.

2. Implementation of infrastructural developments.

3. Placement and testing of infrastructure elements.

4. Educate participants.

5. Application of a proposal system.

6. Functional analysis, correction.

7. Extension of the proposal system.

The implementation of the steps of the planning and implementation process is presented in the next section through the description of a specific project, which has already been implemented in practice.

\section{PROCESS OF DESIGN AND IMPLEMENTATION OF THE SYSTEM}

Applying a well-functioning proposal system requires the implementation of two sub-processes, namely the design and implementation process. In the following, the steps applied by the Institute of Logistics of the University of Miskolc to improve the institutional processes (administration, education, research) are presented [5].

The process of designing the proposal system [3]:

1. Development of a motivation system: The proposal system will be developed for the employees and students of the Institute of Logistics, so the motivation system should also encourage these actors to submit proposals. Adequate motivation to apply the system effectively must include transparent processes, clear feedback deadlines, and financial and / or moral appreciation. In our case, the feedback deadline was set at 5 working days (the developed processes will be described later). When designing the system, we did not define a separate tool for material and/or moral ranking, as we assumed that the application of the system was in the interest of all actors at the same time.

2. Establishment of an organization responsible for the operation: In terms of the operation of the system, the roles of proposer (students, lecturers), coordinator (institute director) and system developer have been established. With a significant increase in the number of proposals, decentralized coordination may be needed at a later stage.

3. Operational processes and development of a uniform set of rules: Incoming proposals are checked by the director of the institute on a weekly basis, for which the delegation of tasks and feedback to the proposer must take place within 5 working days. A personal statement is prepared for each semester from the feasible proposals.

4. Elaboration of applicable forms: The data structure of the forms can be found at https://logcrm.uni-miskolc.hu. Three categories have been developed, namely general proposal making, course rating, and lecturer rating. 


\begin{tabular}{|c|c|c|}
\hline Proposal & Course rating & Lecturer rating \\
\hline proposer's name & proposer's name & lecturer'name \\
\hline contact (e-mail) & contact (e-mail) & course title \\
\hline $\begin{array}{c}\text { relationship with } \\
\text { the University } \\
\text { (industrial } \\
\text { partner, lecturer, } \\
\text { student) }\end{array}$ & $\begin{array}{c}\text { course to be } \\
\text { rated }\end{array}$ & 7 rating asspects \\
\hline proposal & $\begin{array}{c}\text { lecturers of the } \\
\text { course }\end{array}$ & proposal \\
\hline captcha & 5 rating aspects & contact (e-mail) \\
\hline $\begin{array}{c}\text { data mana- } \\
\text { gement plan }\end{array}$ & $\begin{array}{c}\text { Proposal for } \\
\text { course } \\
\text { development }\end{array}$ & captcha \\
\hline & Captcha & $\begin{array}{c}\text { data mana- } \\
\text { gement plan }\end{array}$ \\
\hline
\end{tabular}

Table 1. Required data for submission
5. Development of the concept of applicable software support: The proposal system provides an opportunity for electronic submission, the relevant screen layouts of which are shown in Figures 2 and 3.

The data belonging to the received proposals must be viewable, queried and maintained in a separate administrative interface to be developed for this purpose (Fig.3).

6. Defining the rating indicators of the proposal system: It is planned to rate the operation of the system by determining the number of proposals received per semester, the share of proposals that can be implemented, and the number of proposals that can be implemented, broken down by person.

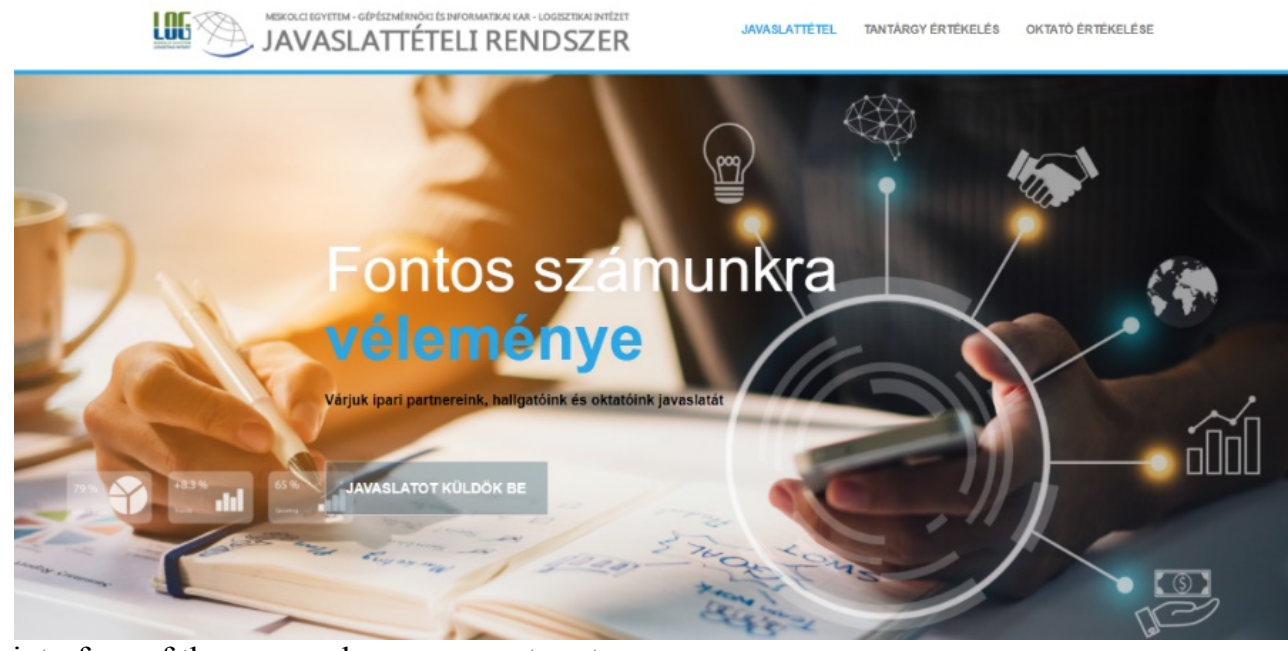

Fig. 2. User interface of the proposal management system

Process for introducing a proposal system [3]:

1. Determining the implementation schedule and cost allocation: Following the planning process, the major phases of implementation should be defined by filling in the data in Table 2 .

2. Implementation of infrastructural developments:
In this phase, the web application defined in the planning phase was created.

3. Placement and testing of infrastructural elements: The placement and testing of the developed application on the server was realized in this phase.

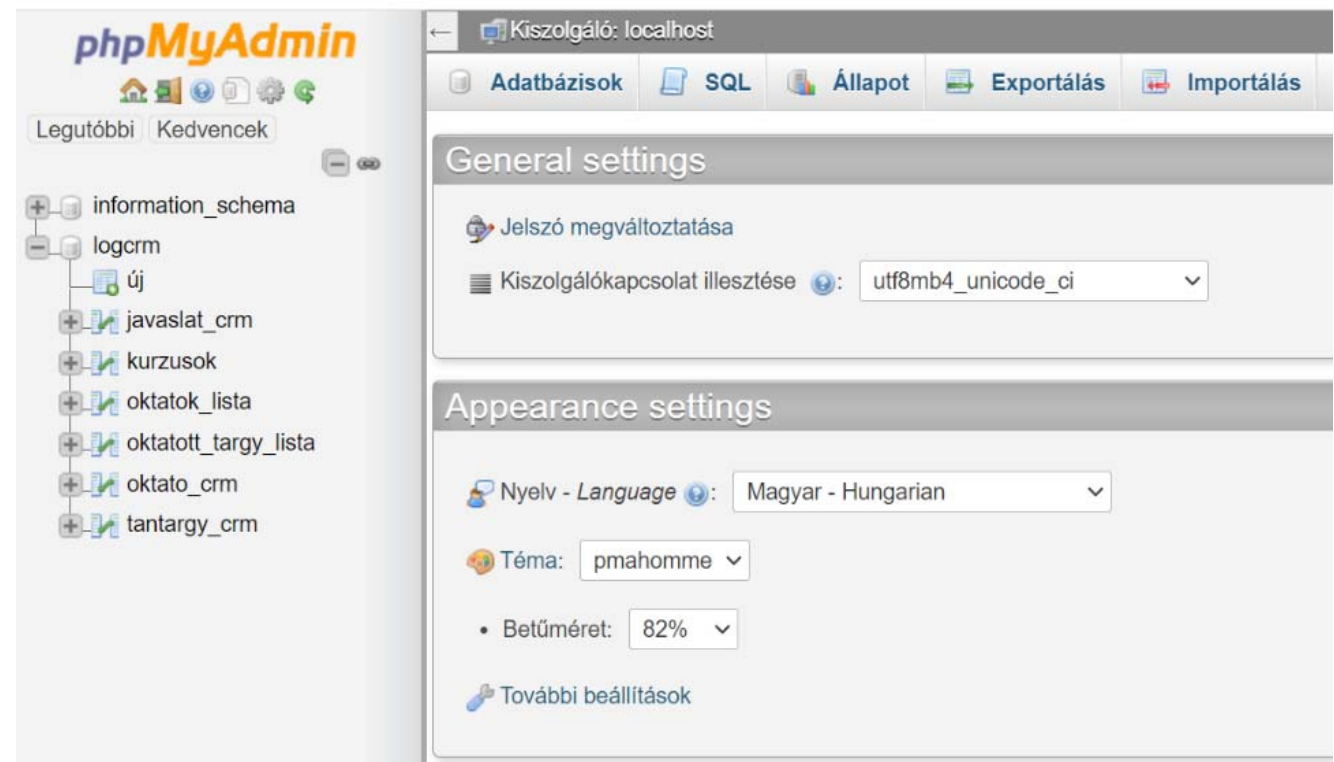

Fig. 3. Administration interface of the database management system 
4. Training of participants: The target group was informed about the operation of the developed system in the form of an electronic message.

5. Application of the proposal system: After informing students, lecturers and industrial partners, it was possible to apply the established proposal system.

6. Functional analysis, correction: During the operational analysis, it was found that only a few proposals were received, which was attributed to the fact that we did not initially associate any financial and / or moral assessments with the submission of the proposals. This has been adjusted in such a way that, based on the number of proposals that can be introduced, a ranking of teachers and students will be determined separately at the end of each semester and, with the consent of the persons concerned, published. Based on the order, students receive extra points (1st place: $25 \%$ of the maximum score, 2 nd place: $20 \%$, then $5 \%$ ) for the subjects related to process development (lean basics, lean logistics, lean 4.0, etc.). decreases for the next persons in the ranking, so the first 5 places have an advantage in the ranking of courses). Instructors will be encouraged in connection with the performance appraisal system under development.

7. Extension of the proposal system [4]: The developed proposal system can be used to improve the processes of other organizational units after minimal modification, however, this requires a re-examination of the motivation system applied to our sample system and further testing of operational processes.

\begin{tabular}{|l|l|l|l|l|l|l|c|}
\hline \multicolumn{1}{|c|}{ Task } & Deadline & Responsible & Approve & Supporting & Informed & Consulted & Budget \\
\hline$\ldots$ & & & & & & & \\
\hline
\end{tabular}

Table 2. Determining the implementation schedule and cost allocation

\section{SUMMARY}

The paper has presented one of the most important tools for the development of logistics processes, namely the proposal system. With the help of this tool, the loss associated with not using the knowledge and creativity of employees can be reduced in both the production and service sectors. The Institute of Logistics of the University of Miskolc has developed its own proposal system for the development of institutional processes, which is currently in the analysis and correction phase of the implementation process. It is important to state at this stage that the driving force of the proper functioning is the development of the appropriate motivation system, in order to overcome which challenge it became necessary to correct the previous ideas. In our opinion, with the proper functioning of the proposal system, long-term development can be achieved in terms of the administrative processes of the institute, the quality of teaching and research activities.

\section{REFERENCES}

[1] Jefrey K. Liker: A TOYOTA MÓDSZER - 14 vállalatirányítási alapelv, ISBN 978-963-9686-434, HVG Kiadó Zrt., Budapest, 2008.

[2] Pardavi, M.: Hány forintot ér egy jó ötlet a magyar gyárakban?, https://autopro.hu/gyartok/ (letöltés: 2021. 02.10.)

[3] Tamás, P., Illés, B., Dobos, P., Seres, L.: Lean módszerek a logisztikában, ISBN 978-615-562659-3, Miskolci Egyetemi Kiadó, 2021.

[4] Tamás, P.: Examining the possibilities for efficiency improvement of SMED method using simulation modelling, MANUFACTURING TECHNOLOGY $17: 4$ pp. 592-597. , 7 p., 2017.

[5] Tamás, P., Varga, A.: Javaslattételi rendszer szerepe a folyamatfejlesztésben, In: Barabás, István (szerk.) XXIX. Nemzetközi Gépészeti Konferencia OGÉT 2021, Kolozsvár, Románia : Erdélyi Magyar Müszaki Tudományos Társaság (EMT) (2021) pp. 327-330. , 4 p.

Authors: Dr. habil. Péter Tamás PhD, University of Miskolc, Faculty of Mechanical Engineering and Informatics, Institute of Logistics, H-3515 MiskolcEgyetemváros, Hungary, tel.: +36(46)565-111(20-26), Dr. Attila K. Varga PhD, University of Miskolc, Faculty of Mechanical Engineering and Informatics, Institute of Automation and Infocommunication, H-3515 Miskolc-Egyetemváros, Hungary, tel.: +36(46)565111(19-46)

E-mail: alttpeti@uni-miskolc.hu varga.attila@uni-miskolc.hu 